\title{
CAṔ́tULO 13
}

\section{PATRIMÔNIO, TURISMO E PERTENCIMENTO: IDENTIDADES RETRATADAS NA SIERRA DE FRANCIA, ESPANHA}

DOI: http:// dx.doi.org/10.18616/plansus13

Adilson Tadeu Basquerote 
A sociedade contemporânea passa por significativas transformações no modo de vida e nas formas de organização social. Nesse cenário, distintas formas de relações sociais se estabelecem e promovem a intensificação das redes de sociabilidade que acarretam transformações culturais em um ritmo acelerado as quais tendem a ocasionar a padronização e a homogeneização cultural. Nessa direção, Hall $(2004$, p. 75) menciona que

Quanto mais a vida social se torna mediada pelo mercado global de estilos, lugares e imagens, pelas viagens internacionais, pelas imagens da mídia e pelos sistemas de comunicação globalmente interligados, mais as identidades se tornam desvinculadas - desalojadas - de tempos, lugares, histórias e tradições específicos e parecem "flutuar livremente".

De forma oposta, intensificam-se discursos que valorizam a diversidade cultural e natural dos lugares e de suas populações, originando tendências que valorizam e exprimem suas particularidades históricas, sociais, culturais e naturais. Em consonância com essa tendência, distintos lugares buscaram potencializar seus recursos naturais, sociais e culturais como ativos para estratégias de desenvolvimento, ancoradas na criação e reconstrução de sua própria identidade. Destarte, coaduna-se à concepção de identidade territorial e de pertencimento expressas por Raffestin (1993, p. 144),

Entende-se que as relações de identidade e pertencimento ao lugar são mescladas no processo de apropriação e territorialização do espaço. Isto é possível quando os sujeitos desenvolvem, neste local, valores atrelados aos seus sentimentos e à sua identidade cultural e simbólica, recriando o espaço onde vive ao qual se identificam e se sentem pertencer. 
Portanto, a construção de territorialidades a partir da cultura local favorece a valorização desses territórios. Sob essa óptica, a reprodução do modo de vida e a realização das atividades práticas e sociais vinculam-se ao território como o lugar essencial. Avalizando, assim, o exposto por Tuan(1983, p.74) quando sinaliza que “[...] olugar é balizado pelo tripé: percepção, experiência e valores".

À luz dessas tendências, observa-se a construção de uma identidade territorial ao sul da província de Salamanca, denominada Sierra de Francia, na Comunidad Autónoma de Castilla y León, Espanha. Composta por $18 \mathrm{mu}$ nicípios, a região busca valorizar o patrimônio natural, por situar-se dentro do Parque Natural de Las Batuecas e cultural definido historicamente pela coexistência de judeus, muçulmanos e cristãos e pela forte migração ocorrida na segunda metade do século XX. A Figura 1 apresenta a região de Sierra de Francia e seus respectivos municípios ao sul, na província de Salamanca.

Figura 1 - Municípios da Sierra de Francia, província de Salamanca, Espanha

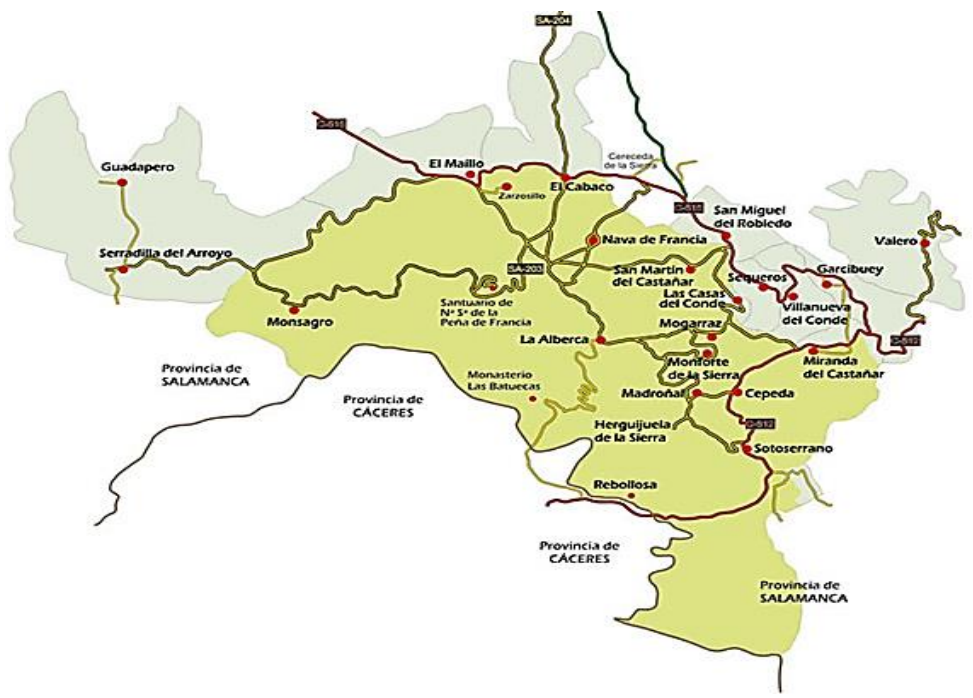

Fonte: Turismo Sierra de Francia (s.d., n.p.). 
Dentre os municípios da região que se destacam na preservação do patrimônio e no turismo, encontra-se Mogarraz, que nos últimos anos tem transformado suas ruas em uma "galeria de arte" ao ar livre, a partir da Série Retrata $2 / 388$, a qual representa o resgate da memória dos antepassados. Nela estão expostas nas fachadas das casas 388 retratos dos moradores que as habitavam na década de 1960 e que optaram por permanecer no pueblo ${ }^{1}$ no período de intenso êxodo rural na região. Além dessas imagens, atualmente o acervo de fotografias vem sendo ampliado e já alcançou aproximadamente 800 retratos de distintas gerações. Sob esse ínterim, o artigo analisa como a Série Retrata 2-388 impulsionou o turismo no município de Mogarraz e qual é a percepção dos moradores sobre a influência dela na preservação do patrimônio e na identificação territorial local.

\section{METODOLOGIA}

Devido às suas características, a pesquisa ${ }^{2}$ em tela tem natureza qualitativa (BOGDAN; BIKLEN, 1994) e foi realizada por meio de estudo de caso que, para Yin (2001, p. 32), "[...] é uma investigação empírica de um fenômeno contemporâneo dentro de um contexto da vida real, sendo que os limites entre o fenômeno e o contexto não estão claramente definidos". Configura-se, logo, como uma abordagem etnometodológica ao esclarecer de que

Maneira as coisas vêm a ser como são nos grupos sociais, de que maneira cada grupo e cada membro apreende e dá sentido à realidade e por quais processos intersubjetivos a mediação da linguagem entre os grupos e seus lugares constrói a realidade social que afirmam. (COULON, 1995, p. 90).

1 Forma como são chamadas as pequenas cidades espanholas.

2 O presente estudo foi realizado com o apoio da Coordenação de Aperfeiçoamento de Pessoal de Nível Superior (CAPES) - Brasil - Código de Financiamento 001. 
Para a coleta de dados, utilizaram-se entrevistas semiestruturadas (FLICK, 2013) compostas por 13 perguntas, realizadas com 20 Mogarrenhos de distintas faixas etárias, com o objetivo de observar se as percepções se assemelhavam ou diferiam-se de acordo com as idades. Além disso, entre os entrevistados, buscaram-se cidadãos que compuseram o arquivo fotográfico de 1967, os quais ainda permaneciam vivos. As entrevistas foram analisadas por meio do método de Análise do Discurso (ORLANDI, 2003). Ademais, realizaram-se registros fotográficos em dezembro de 2015 e fevereiro de 2016, com o objetivo de coletar o maior número possível de informações sobre os sujeitos e seu lugar de vivência.

\section{RESULTADOS}

Município da província de Salamanca, Mogarraz possui uma área total de pouco mais de $9 \mathrm{~km}^{2}$, localizado inteiramente na região conhecida como Sierra de Francia, distante $80 \mathrm{~km}$ da capital provincial. De acordo com Ramírez (2012), há registros de ocupação humana no município desde a Idade Antiga, porém a maior parte da atual estrutura urbana data da ocupação e do repovoamento realizados por franceses no século XI. A cidade conserva estrutura urbanística com típicas características medievais, com ruas estreitas e traçado regular que lhe conferiram, em 1998, o título de Patrimônio de Interesse Nacional, por seu Conjunto Histórico Artístico (RAMÍREZ, 2012). Recentemente, a cidade foi eleita um dos "Pueblos mas bonitos de España" (Povoados mais bonitos da Espanha).

Dotada de apenas um núcleo populacional, que no passado alcançou mais de 1100 habitantes, atualmente residem no município aproximadamente 275 pessoas $^{3}$, embora nos fins de semana e no período de férias o pueblo apresenta uma densidade populacional bem superior, devido aos migrantes ou familiares que regressam temporariamente. Por essa razão, existe uma frase

3 Informação disponibilizada pelo Instituto Nacional de Estadística - INE. Disponível em: https://www.ine.es/dyngs/INEbase/es/categoria.htm?c=Estadistica_P\&cid=1254734710984. Acesso em: 06 ago. 2019. 
intensamente conhecida na região que diz "Me vuelvo al Pueblo" (volto para o Pueblo), em referência à quantidade de pessoas que mantêm lações próximos com a cidade de origem ou com alguém que migrou dela. A Figura 2 apresenta a Província de Salamanca, com destaque à posição geográfica do município de Mogarraz.

Figura 2 - Província de Salamanca e localização de Mogarraz - Espanha

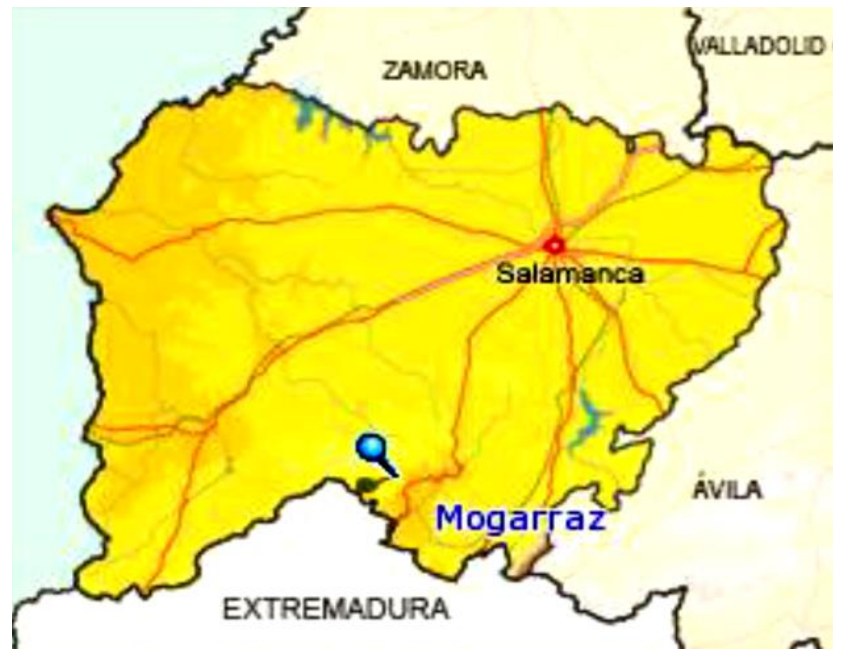

Fonte: Turismo Sierra de Francia (s.d., n.p.).

Mogarraz é um típico "pueblo" serrano, com edificações de três pisos, construídas mesclando-se madeira, tijolo e pedra, os quais foram dispostos de forma irregular. Situada entre os municípios de Miranda del Castañar e La Alberca, apresenta importantes e emblemáticos edifícios, como a Plaza Mayor (Praça Central), a Fuente del Humilladero (Fonte do Heremita), a Igreja da Virgen de las Nieves (construída no século XVII com função defensiva e de refúgio, ela abriga a padroeira da cidade, a Virgem das Neves) e o Balcón de Mogarraz (famoso hotel e restaurante localizado em uma das casas mais antigas da cidade). A Figura 3 apresenta as casas típicas da região serrana de Salamanca, mesclando tijolo, madeira e pedra. 
Figura 3 - Casas típicas da região serrana de Salamanca

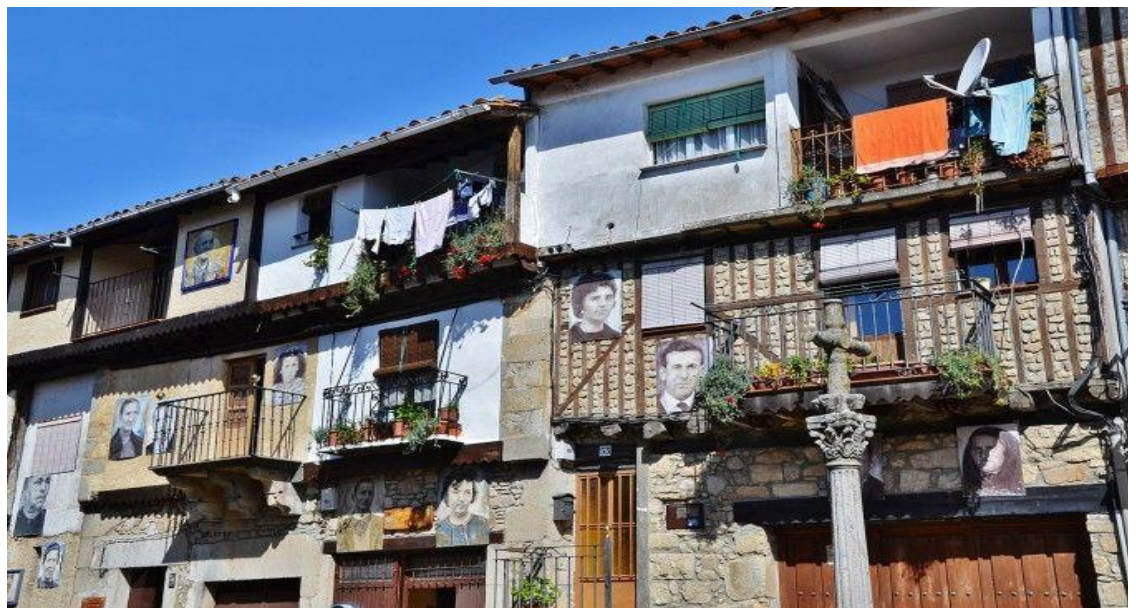

Fonte: Acervo pessoal do autor (2016).

A cidade se destaca pela manutenção de suas tradições religiosas, como o Cerdo de San Antón (Porco de Santo Antônio), também chamado Cochino de San Antón, evento realizado desde o início do século III d.C., e pelos epigramas com motivos religiosos esculpidos nas vergas das portas de entrada das casas. Na gastronomia, destacam-se as famosas castanhas servidas assadas, caramelizadas ou como ingredientes de distintos pratos e embutidos, preparados à base de carne do porco (Cerdo Serrano) como o chorizo (salame) e morcilla (morcela), além do jamón (presunto cru dessecado em sal, azeite de oliva e especiarias), bastante apreciados pelos nativos e turistas.

No artesanato, é destaque na confecção de joias e trajes tradicionais, bordados à mão, retratando lendas amorosas e épicas da região. Recentemente, a cidade inaugurou o Museo de las artesanías (Museu do Artesanato), dedicado a exibir a memória dos ourives, sapateiros e bordadeiras da região. No local, também se realizam exposições, oficinas e cursos. A Figura 4 apresenta os tradicionais bordados mogarrenhos, que auxiliam na manutenção do patrimônio e que, devido ao recente impulso do turismo, tornaram-se também fonte de renda. 
Figura 4 - Bordados típicos de Mogarraz

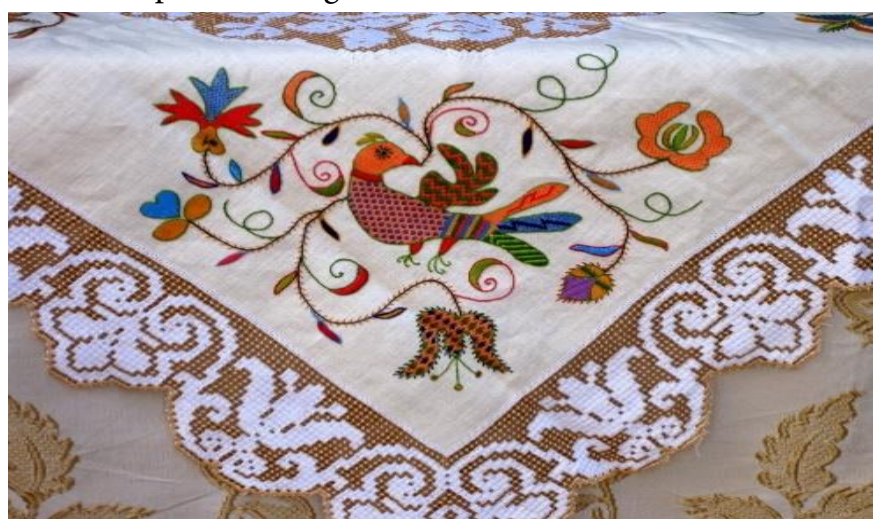

Fonte: Asociación Red Arrayan de Cultura Patrimonio Y Medio Ambiente (2019, n.p.).

Nos últimos anos, Mogarraz tem se destacado também no setor turístico. Visita obrigatória dentre os municípios de Sierra de Francia, que, além dos atrativos culturais, religiosos e naturais, desde 2012, converteu-se em uma sala de exposições ao ar livre a partir de quando foi exposta nas fachadas das casas a Série Retrata 2-388, composta por 388 retratos, pintados pelo professor e artista plástico nascido em Mogarraz, Florencio Maíllo, que migrou para Salamanca aos cinco anos de idade, no período de intenso êxodo rural, o qual ocasionou um significativo declínio populacional no município.

Segundo Maíllo (2009), a origem do arquivo fotográfico remonta ao frio e seco outono de 1967. Na época, o Alcade (prefeito), Dr. Isidoro Herrero Francisco, solicitou a Alejandro Martín Criado, um ex-combatente de guerra, de regresso a Mogarraz, que retratasse todos os moradores - especialmente os adultos - do município para a recontagem da população e a emissão do Documento Nacional de Identidade (DNI), equivalente à Carteira de Identidade. De acordo com Maíllo (2009), Alejandro organizou um espaço nos fundos da residência da família e, de posse de sua câmera Yashica modelo 44 LM, um banco de madeira e um lençol branco, fotografou todos os moradores, que, desse modo, não precisaram se deslocar até a cidade de Bejár, a aproximadamente $45 \mathrm{~km}$ de distância, para obter a foto para o documento. Alejandro 
iniciou a captura de imagens, retratando primeiramente a si, na forma de um autorretrato, vestindo uma jaqueta de aviador marrom, que simbolizava seu passado como piloto da Força Aérea espanhola. Em seguida, foram fotografados um a um, por ordem de afinidade de parentesco, os habitantes do pueblo, gerando o singular acervo fotográfico (RAMÍREZ, 2012).

La serie fotográfica configurada por un total de 388 imágenes está flanqueada por una especialmente emblemática, un autorretrato. En él Alejandro aparece luciendo su flamante chaqueta de aviador marrón, alertándonos sobre la pista de su pasado militar. Agonizaba el mes de octubre $y$ todos los habitantes del pueblo desfilaban puntualmente delante del objetivo de la cámara de Alejandro, situada en la trasera de la vivienda familiar del barrio del Altozano. Allí, ante una inmaculada sábana suspendida sobre una pared de la huerta, ágilmente fueron pasando y posando la última generación de mogarreños que rehusaron emigrar. Éste fue pues el escenario en el que el fotógrafo transciende para siempre, dejando inmortalizados para el futuro a la última estirpe de hombres y mujeres unidos vitalmente al espacio que les vio nacer. La digitalización de las imágenes respetando la ordenación en el proceso de captura nos sitúa ante una procesión caracterizada por las afinidades familiares, padres, hijos, hermanos, cuñados e incluso vecinos, construyendo un álbum de retratos cuando menos singular. (MAÍlLO, 2009, p. 3).

Martin (2016) destaca que, com esmero e paciência, Alejandro imortalizou a fisionomia dos Mogarrenhos de 1967 e que seus registros expressam a realidade dos habitantes do pueblo na época, transparecendo o prestígio social, o luto, a atividade laboral exercida, entre outros aspectos. Maíllo (2009), ao entrevistar os habitantes que foram fotografados na época, identificou que parte da população não sabia antecipadamente que seriam realizadas as fotografias, por isso não teve tempo de preparar-se, de modo a arrumar os cabelos, fazer a barba ou vestir-se com roupas melhores, o que ocasionou certo desconforto 
na época. A Figura 5 ilustra parte do acervo fotográfico criado por Alejandro Martín Criado, no qual é perceptível parte das diferenças mencionadas.

Figura 5 - Fotos realizadas por Alejandro Martín Criado para a confecção do DNI
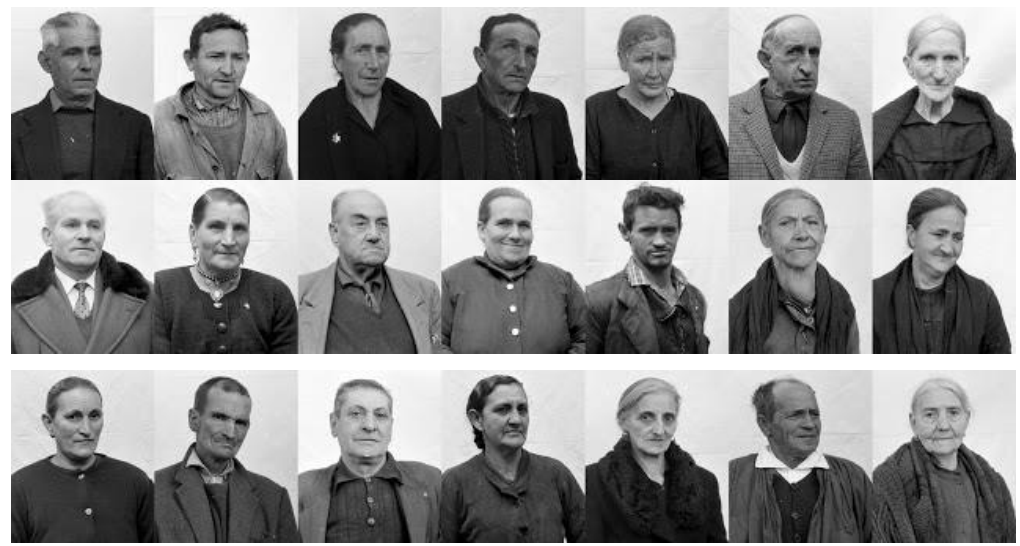

Fonte: Maíllo (2009, p. 3).

De acordo com Maíllo (2009), os negativos dos retratos foram guardados em forma de rolo, dentro de uma caixa de um antigo pluviômetro, no porão da casa da família de Alejandro, e conservaram-se devido às características físicas do local armazenado e da vontade de Ángeles do Nacimiento Lorenzo, sua esposa. Nas palavras do autor,

Pero no seríamos del todo justos si no valorásemos en su preciso término la decisiva aportación de su mujer, Ángeles de Nacimiento Lorenzo, a favor de la preservación de los negativos originales de este insólito registro. Ella, con el extraordinario afán de conservación que caracteriza al género femenino, tramó una inteligente operación gracias a la cual podemos observar lo que nos revela este original catálogo antropológico de Mogarraz de la segunda mitad de los años sessenta. (MAÍlLO, 2009, p. 4). 
Anos mais tarde, em virtude de uma mudança, Alejandro encontrou a caixa com os negativos fotográficos e solicitou a Maíllo a reprodução digital do material, doze imagens de seus familiares (MARTIN, 2016). Ao receber o arquivo, Maíllo surpreendeu-se com a memória antropológica do material e reportou-se às memórias mais remotas de sua vida no pueblo e das pessoas do ano de 1967. Assim, realizou o trabalho e devolveu os negativos a Alejandro. No entanto, não conseguiu desvincular as imagens de sua memória, por isso, mais tarde, procurou a família de Alejandro e pediu-lhe autorização para revelar as fotografias. "Foram horas de trabalho para ordenar e identificar as pessoas retratadas que [...] só foi possível, graças à ajuda de Ángeles e os demais antigos moradores de Mogarraz" (MARTIN, 2016, n.p).

Ramírez (2012) destaca que no ano de 2008, Maíllo iniciou a pintura dos retratos em chapas de metal, utilizando a técnica encáustica, transformando os retratos em tom de preto e branco ou em imagens coloridas, muitas vezes sob a observação de moradores na época retratados os quais ainda estavam vivos. Segundo o autor, o objetivo de Maíllo era concluir as pinturas em quatro anos (2008-2012) para realizar uma exposição temporária dos retratos no mês de agosto de 2012 (MARTIN, 2016). Todavia, o sucesso e a aceitação da população foram tão intensos, que os retratos permaneceram distribuídos pelas ruas do pueblo, convertendo-as em uma galeria de arte a céu aberto, mantendo permanentemente as feições dos moradores, que nos difíceis anos da década de 1960 resistiram ao intenso processo migratório a que foram acometidos os povos serranos de Salamanca.

A Figura 6 apresenta o professor e artista plástico Florencio Maíllo segurando um dos quadros do Projeto Artístico Retrata 2-388, em formato grande, em uma das ruas de Mogarraz, onde, desde 2012, encontram-se fixados, mantendo viva a memória dos antigos moradores e vizinhos. 
Figura 6 - Florencio Maíllo e os retratos de Mogarraz

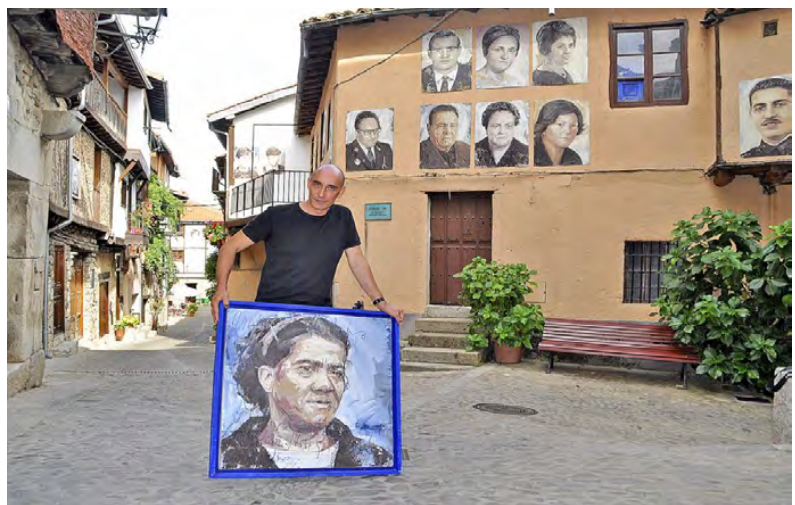

Fonte: Andrés (2017, n.p.).

Assim, gradativamente, os retratos foram sendo dispostos nas fachadas das casas das estreitas ruas do pueblo e passaram a manter viva a memória dos antigos habitantes, gerando a impressão de que eles vigiam as ruas. Segundo Maíllo (2009), os moradores esperaram ansiosos para descobrir se na sua casa seria fixado algum retrato e buscaram acompanhar a montagem da exposição. A Figura 7 apresenta a colocação dos retratos no ano de 2012, denominados pelo próprio artista como uma "Cartografia humana del proprio Pueblo".

Figura 7 - Fixação dos retratos nas fachadas das residências em Mogarraz

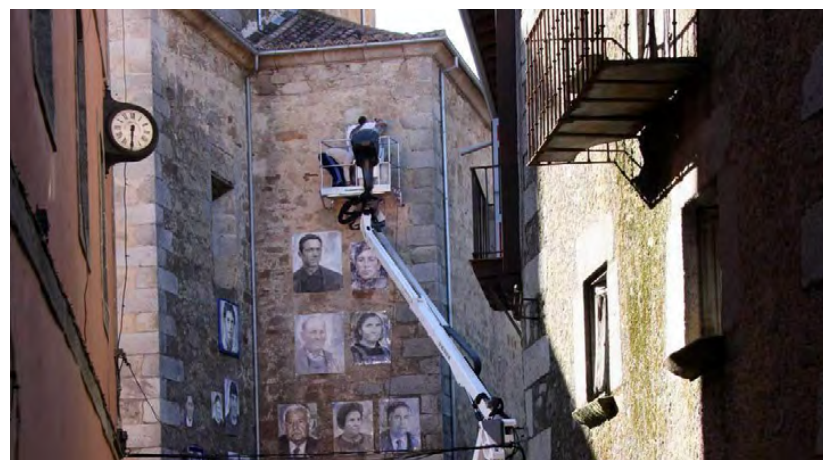

Fonte: Andrés (2017, n.p.). 
De acordo com Ramírez (2012), Maíllo continua seu trabalho de retratar na forma de pintura o povo mogarrenho. Atualmente, são aproximadamente 800 retratos de diferentes gerações, expostos nas casas espalhadas pela cidade, os quais exprimem a relação dos habitantes com o seu passado. Nessa perspectiva, as imagens expressam um valor documentário que, segundo de Kossoy (2001, p. 55), “[...] representam um meio de reconhecimento da cena passada, portanto, uma possibilidade de resgate da memória visual do homem e do seu entorno sócio-histórico". O depoimento de Esperança expressa o apreço pelos retratos, a forma como identificam sua cidade e a história de sua gente.

"Quando eu soube que Maíllo ia pintar os retratos, imaginei que seria interessante, pois manteria viva a memória e a identidade dos antepassados mogarrenhos. Mas não imaginava o quanto isso iria mudar minha percepção sobre a minha história e a do meu Pueblo. Agora, cada vez que vejo a fachada da minha casa, me reporto aos meus pais e a saudade me aperta o peito. Quando saio pra trabalhar, ir ao mercado, vejo a imagem do meu tio, do meu padrinho $e$ isso me faz ser responsável por cuidar da minha cidade também por eles, que um dia decidiram não abandoná-la. É como se eles estivessem aqui, vivos, olhando pra mim. Em um tempo em que os valores estão mudando tão rapidamente, os retratos mantêm viva nossa história. Na casa que eu moro, já moraram bisavós, meus avós, meus pais e agora vive minha família. Nela já temos os retratos de quatro gerações e em breve teremos a minha e de meus filhos". (ESPERANÇA, 55 anos. Entrevista concedida em $17 \mathrm{dez}$. 2015. Tradução nossa).

As afirmações de Esperança reforçam a ideia de que sentimentos que pertencimento e identidade são construídos no ambiente de vivência dos indivíduos, pois ele possibilita aprofundar conhecimentos e rever atitudes, conceitos, valores éticos e estéticos. Assim, a identificação pessoal com os retratos também foi destacada pelos primos Álvaro e Paco, os quais, pela avançada 
idade, são bastante conhecidos no pueblo. Segundo eles, a atual fase do mundo globalizado exprime uma tendência de desvalorização dos valores locais e a perda da identidade; os retratos contribuem para manter viva a memória coletiva dos antepassados, a identificação da origem dos habitantes e a sua relação com o lugar, com seu patrimônio e sua história.

"Para nós de Mogarraz, os retratos são uma memória presente dos antepassados. Hoje em dia, as gerações mais novas se preocupam em saber das novidades que veem na televisão ou na internet, não querem valorizar a história do lugar onde vivem ou saíram. Assim, os retratos nos remetem sempre ao nosso passado, à nossa origem. Quando eu olho para eles, me lembro a minha infância, dos meus parentes, da minha mãe! Lembro das festas do Cerdo de San Antón, das brincadeiras na rua, das dificuldades e necessidades que diárias, dos tempos difíceis que vivíamos na época. Lembro até da senhora Quintina, uma viúva que morava na mesma rua de nossa casa e que me colocava medo, por sua aparência sofrida, pelo habitual preto que vestia, guardando luto pela perda do marido. Me recordo, inclusive, das medalhas presas à sua capa e que eram dele, um soldado morto na guerra". (ÁLVARO, 87 anos. Entrevista concedida em 16 dez. 2015. Tradução nossa).

"Os retratos, pra mim, indicam o que é Mogarraz para sua gente. Eles são a prova de que pertencemos a ele. Cada imagem mostra para quem vive aqui ou para os visitantes o gosto e orgulho que temos deste pedaço de chão encravado na Serra. Temos que ter orgulho de nascer neste lugar e de cuidar dele. Não podemos deixar o mundo moderno apagar nossas origens. Portanto, as imagens representam muito bem a memória dos que decidiram ficar e não desistiram de suas raizes e que, de certa forma, ainda reproduzem na atualidade a história". (PACO, 88 anos. Entrevista concedida em 16 dez. 2015. Tradução nossa). 
Os depoimentos de Esperança, Álvaro e Paco vão ao encontro dos estudos de Jacks (2014, et al.), ao afirmarem que o consumo midiático estimula a perda da identidade local ao proporcionar a oferta de bens, tendências, comportamentos, novidades, identidades, fantasias e desejos. Inobstante isso, Callai (2000) entende que mesmo com a globalização e a tendência de padronização de valores, hábitos, entre outros elementos é no lugar que esse processo se concretiza. Assim, os retratos expostos compõem um itinerário histórico e etnográfico das pessoas que auxiliaram na construção do Pueblo, mantendo viva a memória de distintas gerações que ali viveram ou vivem. A Figura 8 apresenta diferentes gerações de mogarrenhos expostas nas fachadas.

Figura 8 - Diferentes gerações apresentadas nas fachadas das residências em Mogarraz

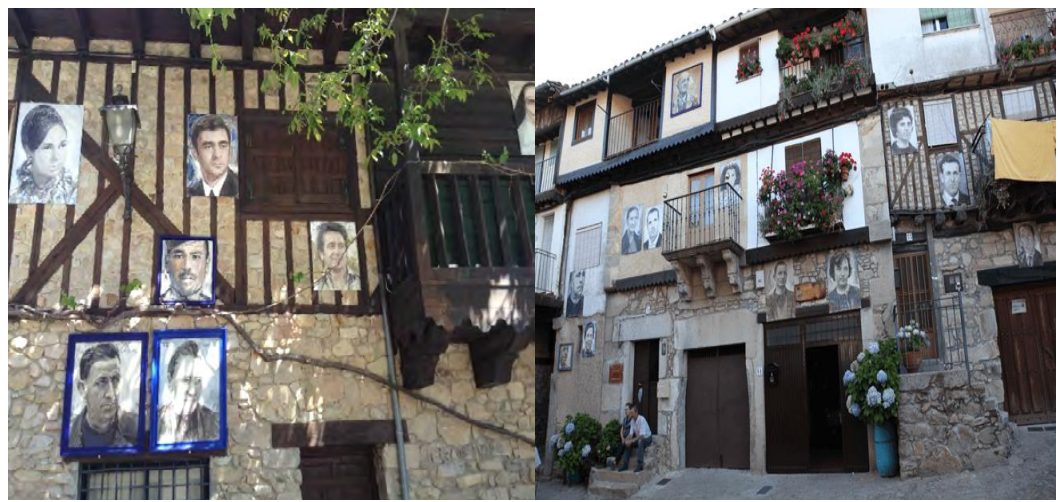

Fonte: Acervo pessoal do autor (2016).

Outro elemento destacado nas entrevistas foi a mudança de postura da população mogarrenha em relação à receptividade dos turistas. A exposição dos retratos, sem dúvida, reforçou o turismo no município à medida que se tornou mais um atrativo a ser oferecido e, consequentemente, um incremento na renda. Além disso, os munícipes passaram a ser mais receptivos, acolhendo os visitantes, oferecendo informações e demostrando orgulho quanto à imagem e à memória de seus antepassados. A fala de Pilar expressa a mudança de postura da população local em relação aos visitantes: 
"O que mais me surpreendeu foi o caráter social, colaborativo e amistoso do nosso povo. Cada pessoa de nossa cidade se converteu em um anfitrião, contando histórias e recordações das pessoas e as histórias que envolvem a exposição. Eu já vi várias vezes os mogarrenhos dando informações aos turistas sobre a história da cidade, dos retratos, de quem são as pessoas que ali estão representadas, como viviam, em que trabalhavam. Em especial os moradores mais antigos, por conhecerem melhor a história, são os que mais gostam de falar sobre os retratos. Nossa gente cada vez mais recebe de forma mais amistosa os turistas e procura fazer com que eles se sintam bem aqui". (PILAR, 44 anos. Entrevista concedida em 12 fev. 2016. Tradução nossa).

O exposto por Pilar vai ao encontro das afirmações de Halbwachs (1990) e Carlos (2007) quando afirmam que o lugar possui memória, que ela é uma construção do passado no presente e que as mudanças no tempo e no espaço proporcionam a construção contínua desse pertencimento. Na mesma direção, Bauman (2005) chama atenção para a necessidade de compreender que pertencimento e identidade são permanentemente construídos. Nas palavras do autor (2005, p. 17),

"Pertencimento" e a "identidade" não têm a solidez de uma rocha, não são garantidos para toda a vida, são bastante negociáveis e revogáveis, e de que as decisões que o próprio indivíduo toma, os caminhos que percorre, a maneira como age - e a determinação de se manter firme a tudo isso - são fatores cruciais tanto para o "pertencimento" quanto para a "identidade.

Em contexto semelhante, Callai (2000) afirma que o lugar é passível de ser sentido, pensado, apropriado e vivido. Nessa direção, Sergio, explicitou a noção de identidade e pertencimento que os retratos expressam. 
"Quando eu comecei a ver os retratos sendo expostos, sinceramente achei estranho e não dei muita importância. À medida que comecei a saber quem eram as pessoas retratadas, o que elas desenvolviam e que relação elas têm com a minha própria história, minha percepção se alterou completamente. Assim, considero que os retratos se fundem à história das casas e das pessoas que as habitaram ou habitam. Hoje eu sei, por exemplo, que um dos retratos que encontra-se na torre da igreja pertence a um senhor que auxiliou na construção da casa da minha família. Outro exemplo é o retrato de uma senhora que era costureira e doava roupas pra minha avó, que era de origem bastante humilde. Acredito que se fosse em outra cidade e com outras pessoas, eu talvez não teria a mesma percepção e valoração em relação aos retratos". (SERGIO, 28 anos. Entrevista concedida em 13 fev. 2016. Tradução nossa).

As constatações de Sergio avalizam as de Kossoy (2001) quando defende que as imagens expressam um “[...] valor documentário, representam um meio de reconhecimento da cena passada, portanto, uma possibilidade de resgate da memória visual do homem e do seu entorno sócio-histórico" (KOSSOY, 2001, p. 55). A Figura 9 apresenta Mogarraz em dois períodos distintos. O primeiro revela os retratos da parede da igreja da Virgen de las Nieves, onde estão os retratos de pessoas cujas casas foram destruídas e outro retrato da parte mais recente da cidade.

Figura 9 -Mogarraz em diferentes momentos históricos

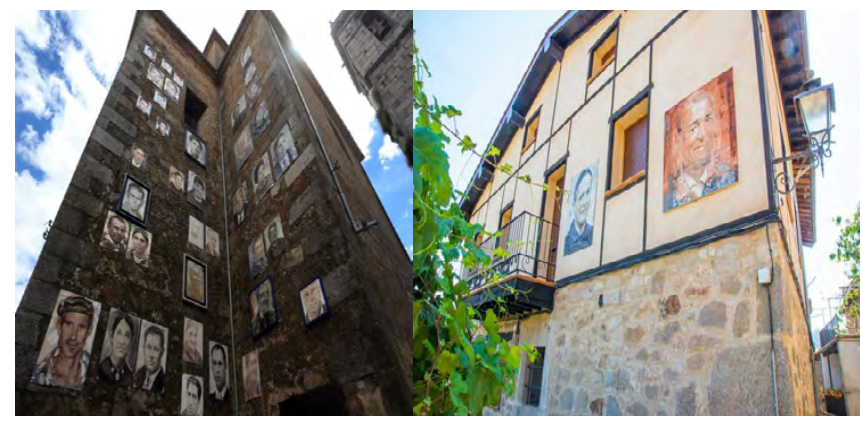

Fonte: Acervo pessoal do autor (2016). 
Além do patrimônio histórico construído ao longo dos séculos na região da Sierra de Francia, é indiscutível que em Mogarraz o fluxo de turistas foi intensificado a partir da exposição da Série Retrata 2-388. Sobre esse hiato, Carlota explicitou a expansão do turismo no município a partir da exposição dos retratos dos "vizinhos de 1967", como também sobre o modo como foi conhecida a exposição fotográfica.

"Por nossas características ambientais, históricas, culturais $e$, principalmente, arquitetônicas, nosso município recebe turistas em todas as estações do ano. Caminhar pelas nossas estreitas ruas é voltar na história das cidades medievais de montanha, com casas tradicionais de alvenaria mescladas com treliças de madeira, tijolos e pedra. Algumas delas apresentam varandas de ferro forjado, com símbolos nas vigas das portas, referenciando o ano da construção ou à fé dos que tornaram-se judeus conversos no período da inquisição. Os visitantes se encantam com fontes de água dispostas pelas ruas, que somadas chegam a catorze (mais antiga, datada de 1600). No entanto, a partir de 2009, quando foram expostos os primeiros retratos, progressivamente $o$ fluxo de turistas cresce a cada ano e atualmente eles são o principal motivo de recebermos tantos visitantes, o que nos obriga a valorizar ainda mais o nosso lugar, nossa história e nosso rico patrimônio". (CARLOTA, 31 anos. Entrevista concedida em 14 fev. 2016. Tradução nossa).

O depoimento de Carlota avaliza o estudo de Carlos (1996, p. 28) quando expressa que o "[...] lugar é, em sua essência, produção humana, porquanto se produz na relação entre espaço e sociedade, o que significa criação, estabelecimento de uma identidade entre comunidade e lugar [...]. Nesse cenário, a Série Retrata 2-388 contribui para desenvolver a noção de pertencimento, de valorização das memórias, do valor histórico, comercial e turístico. 


\section{CONSIDERAÇÕES FINAIS}

O capítulo analisou como o projeto Retrata 2-388 impulsionou o turismo no município de Mogarraz e qual é a percepção dos moradores sobre a influência do projeto na preservação do patrimônio local. Percebeu-se que a população local mantém uma íntima relação de identificação com os retratos fixados nas fachadas das residências. Para ela, as imagens representam sua própria história por meio de seus antepassados, os quais, em um período economicamente adverso, optaram por permanecer no pueblo, mantendo as construções, suas características culturais e patrimoniais.

Revelou-se que os retratos compõem uma memória viva e presente para as novas gerações que, diariamente, mantêm contato com as imagens e o que elas representam. Para os munícipes, mostrar aos visitantes o seu pueblo, a sua história por meio dos retratos tem se constituído motivo de orgulho e de satisfação. Outrossim, as imagens têm atraído visitantes de várias partes do mundo e tornaram-se um atrativo turístico que proporciona uma nova dinâmica econômica ao município e à região da Sierra de Francia, contribuindo para a desaceleração do êxodo populacional na região.

Ademais, constatou-se que a exposição dos retratos nas fachadas promoveu alterações na forma como a população local recepciona os turistas. Por tratarem-se de seus antepassados, com os quais há um vínculo afetivo, os mogarrenhos passaram a ser mais receptivos, prestando informações gentilmente, orientando os turistas de forma mais cortês, amistosa e gentil. Assim, a partir dos protocolos dos entrevistados, comprovou-se que o pueblo conecta-se a outras realidades por meio de seus visitantes, sem, contudo, perder a identidade local, que se tornou um dos atrativos para os turistas.

Obstante isso, verificou-se que os retratos de Mogarraz se configuram identidades retratadas à medida que a história das pessoas retratadas se funde com a história da cidade, das casas e das pessoas que vivem nela. Assim sendo, promovem a identificação dos habitantes com o território e desenvolvem a noção de pertencimento (CALLAI, 2000), de vínculos afetivos (TUAN, 
1983) e de compreensão das relações e do processo histórico nele estabelecido (CARLOS, 2007).

Por fim, comprovou-se que a presença dos retratos para parte das pessoas entrevistadas, em especial os mais jovens, não é percebida como “[...] reações a situações novas que ou assumem a forma de referência a situações anteriores, ou estabelecem seu próprio passado através da repetição quase obrigatória" (HOBSBAWN, 1997, p. 9). De maneira indubitável, pesquisas mais abrangentes e em diferentes situações permitirão uma melhor compreensão dos impactos promovidos pela presença dos retratos de Mogarraz.

\section{REFERÊNCIAS}

ANDRÉS, J. P. El proyecto de Mogarraz es la cartografía humana de todo un Pueblo. Diário de Valladolid, 12 de agosto de 2017. [Não paginado]. Disponível em: http://www.diariodevalladolid.es/noticias/valladolid/elproyecto-mogarraz-es-cartografia-humana-todo-pueblo_94750.html. Acesso em: 15 jul. 2020.

ASOCIACIÓN RED ARRAYAN DE CULTURA PATRIMONIO Y MEDIO AMBIENTE. Plan Entre-2. Publicado em 2019. Disponível em: http:// bordadoserrano.es/masinformacion/. Acesso em: 15 jul. 2020.

BAUMAN, Z. Identidade. Entrevista a Benedetto Vecchi. Tradução de Carlos Alberto Medeiros. Rio de Janeiro: Zahar, 2005.

BOGDAN, R. C.; BIKLEN, S. K. Investigação qualitativa em educação: uma introdução à teoria e aos métodos. Lisboa: Porto Editora, 1994.

CALLAI, H. C. Estudar o lugar para compreender o mundo: o lugar na geografia. In: CASTROGIOVANNI, A. (org.). Ensino de geografia: práticas e textualizações no cotidiano. 7. ed. Porto Alegre: Mediação, 2000, p. 83-131.

CARLOS, A. F. O lugar no/do mundo. São Paulo: FFLCH, 2007. 
CARLOS, A. F. O Turismo e a produção do não-lugar. In: YÁZIGI, E.; CARLOS, A. F. A.; CRUZ, R. C. A. (orgs.). Turismo: Espaço, paisagem e cultura. São Paulo: Hucitec, 1996, p. 25-37.

COULON, A. Etnometodologia. Tradução de Ephraim Ferreira Alves. Petrópolis: Vozes, 1995.

FLICK, U. Introdução à metodologia de pesquisa: um guia para iniciantes. Porto Alegre: Penso, 2013.

HALBWACHS, M. A memória coletiva. São Paulo: Vértice, 1990.

HALL, S. Identidades culturais na pós-modernidade. Tradução de Tomaz. T. da Silva e Guacira Louro. 2. ed. Rio de Janeiro: DP\&A Ed., 2004.

INSTITUTO NACIONAL DE ESTADÍSTICA - INE. INEbase de Demografia y poblaçón. Sem data de publicação. Disponível em: https://www.ine.es/dyngs/ INEbase/es/categoria.htm?c=Estadistica_P\&cid=1254734710984. Acesso em: 06 ago. 2019.

JACKS, N.; TOALDO, M.; WOTTRICH, L.; OIKAWA, E.; NOLL, G. Jovem e consumo midiático: dados preliminares do estudo piloto e da pesquisa exploratória. In: ENCONTRO ANUAL DA COMPÓS, 23, 2014, Belém. Anais... Belém: Universidade Federal do Pará, 2014, p. 1-18.

KOSSOY, B. Fotografia e história. São Paulo: Ateliê Editorial, 2001.

MAÍLLO, F. La fotografía como esencia gemela. Una cartografía antropológica de Mogarraz. La Peña de Mogarraz. XXXIIV aniversário. N. 5, 2009. Dirección: Carmen Herrera Maíllo. Redacción: Eugenio Cascón Martín. Depósito Legal: AS: 3572-2005.

MARTIN, H. Los últimos de la Sierra de Francia. Diário de Valladolid, 18 de novembro de 2016. [Não paginado]. Disponível em: http://www. diariodevalladolid.es/noticias/laposada/ultimos-sierra-francia_72381.html. Acesso em: 19 jun. 2019. 
ORLANDI, E. P. Análise de Discurso: princípios e procedimentos. Campinas, SP: Pontes, 2003

RAFFESTIN, C. Por uma Geografia do Poder. São Paulo: Ática, 1993.

RAMÍREZ, F. C. Retratos de Mogarraz por Florencio Maíllo. Cultumaramas, 30 de agosto de 2012. [Não paginado]. Disponível em: http://www.culturamas. es/blog/2012/08/30/retratos-de-mogarraz-por-florencio-maillo/. Acesso em: 19 jun. 2019.

TUAN, Y. Espaço e Lugar: a perspectiva da experiência. São Paulo: DIFEL, 1983. TURISMO SIERRA DE FRANCIA. Municipios de la Mancomunidad. Sem data de Publicação. Disponível em: http://turismosierradefrancia.es/. Acesso em: 15 jul. 2020.

YIN, R. K. Estudo de caso: planejamento e métodos. Porto Alegre: Bookman. 2001.

\section{Entrevistas $^{4}$}

ÁLVARO, 87 anos. Entrevista concedida em 16 dez. 2015. Tradução nossa.

CARLOTA, 31 anos. Entrevista concedida em 14 fev. 2016. Tradução nossa.

ESPERANÇA, 55 anos. Entrevista concedida em 17 dez. 2015. Tradução nossa.

PACO, 88 anos. Entrevista concedida em 16 dez. 2015. Tradução nossa.

PILAR, 44 anos. Entrevista concedida em 12 fev. 2016. Tradução nossa.

SERGIO, 28 anos. Entrevista concedida em 13 fev. 2016. Tradução nossa.

4 A fim de resguardar a integridade dos entrevistados, eles foram mencionados neste capítulo por meio dos nomes fictícios Álvaro, Carlota, Esperança, Paco, Pilar e Sergio, por isso também não aparecem os seus nomes patronímicos. 